\title{
GnRH receptor activation competes at a low level with growth signaling in stably transfected human breast cell lines
}

Kevin Morgan ${ }^{1 *}$, Colette Meyer ${ }^{2}$, Nicola Miller ${ }^{1}$, Andrew H Sims², llgin Cagnan², Dana Faratian², David J Harrison², Robert P Millar ${ }^{1}$ and Simon P Langdon ${ }^{2^{*}}$

\begin{abstract}
Background: Gonadotrophin releasing hormone $(\mathrm{GnRH})$ analogs lower estrogen levels in pre-menopausal breast cancer patients. GnRH receptor (GnRH-R) activation also directly inhibits the growth of certain cells. The applicability of $\mathrm{GnRH}$ anti-proliferation to breast cancer was therefore analyzed.

Methods: GnRH-R expression in 298 primary breast cancer samples was measured by quantitative immunofluorescence. Levels of functional GnRH-R in breast-derived cell lines were assessed using ${ }^{125}$ /-ligand binding and stimulation of ${ }^{3} \mathrm{H}$-inositol phosphate production. Elevated levels of $\mathrm{GnRH}-\mathrm{R}$ were stably expressed in cells by transfection. Effects of receptor activation on in vitro cell growth were investigated in comparison with IGFI and EGF receptor inhibition, and correlated with intracellular signaling using western blotting.

Results: GnRH-R immunoscoring was highest in hormone receptor (triple) negative and grade 3 breast tumors. However prior to transfection, functional endogenous GnRH-R were undetectable in four commonly studied breast cancer cell lines (MCF-7, ZR-75-1, T47D and MDA-MB-231). After transfection with GnRH-R, high levels of cell surface GnRH-R were detected in SVCT and MDA-MB-231 clones while low-moderate levels of GnRH-R occurred in MCF-7 clones and ZR-75-1 clones. MCF-7 sub-clones with high levels of GnRH-R were isolated following hygromycin phosphotransferase transfection. High level cell surface $\mathrm{GnRH}-\mathrm{R}$ enabled induction of high levels of ${ }^{3} \mathrm{H}$-inositol phosphate and modest growth-inhibition in SVCT cells. In contrast, growth of MCF-7, ZR-75-1 or MDA-MB-231 clones was unaffected by GnRH-R activation. Cell growth was inhibited by IGF-I or EGF receptor inhibitors. IGF-I receptor inhibitor lowered levels of p-ERK1/2 in MCF-7 clones. Washout of IGF-I receptor inhibitor resulted in transient hyper-elevation of $\mathrm{p}$-ERK1/2, but co-addition of GnRH-R agonist did not alter the dynamics of ERK1/2 rephosphorylation.
\end{abstract}

Conclusions: Breast cancers exhibit a range of GnRH-R immunostaining, with higher levels of expression found in triple-negative and grade 3 cancers. However, functional cell surface receptors are rare in cultured cells. Intense GnRH-R signaling in transfected breast cancer cells did not markedly inhibit growth, in contrast to transfected HEK 293 cells indicating the importance of intracellular context. GnRH-R signaling could not counteract IGF-I receptortyrosine kinase addiction in MCF-7 cells. These results suggest that combinatorial strategies with growth factor inhibitors will be needed to enhance $\mathrm{GnRH}$ anti-proliferative effects in breast cancer

\footnotetext{
* Correspondence: kevinmorganxhrsu@gmail.com; Simon.Langdon@ed.ac.uk 'Medical Research Council Human Reproductive Sciences Unit, The Queen's Medical Research Institute, Little France Crescent, Old Dalkeith Road, Edinburgh EH16 4TJ, UK

${ }^{2}$ Breakthrough Research Unit and Division of Pathology, Institute of Genetics and Molecular Medicine, University of Edinburgh, Crewe Road, Edinburgh, EH4 2XU, UK

Full list of author information is available at the end of the article
}

\section{() Biomed Central}

(C) 2011 Morgan et al; licensee BioMed Central Ltd. This is an Open Access article distributed under the terms of the Creative Commons Attribution License (http://creativecommons.org/licenses/by/2.0), which permits unrestricted use, distribution, and reproduction in any medium, provided the original work is properly cited. 


\section{Background}

Endocrine suppression using gonadotropin releasing hormone $(\mathrm{GnRH})$ analogs such as goserelin (a superagonist) is commonly used for the treatment of premenopausal estrogen-responsive breast cancer because it lowers plasma levels of estrogen by inhibiting secretion of luteinizing hormone and follicle stimulating hormone from the pituitary gland $[1,2]$ and thereby slows estrogen-driven tumor growth.

It has been speculated since a proportion of cancer cells express $\mathrm{GnRH}$ receptor, that activation or inhibition of GnRH receptor signaling may directly affect cell growth [3-5].

This could have therapeutic value in both ER-positive and ER-negative tumors if the GnRH-sensitive population could be identified. A range of in vitro and animal model studies have explored this phenomenon [5-10]. The cellular response to $\mathrm{GnRH}$ receptor activation is complex. Cell-type specific features influencing $\mathrm{GnRH}$ receptor signaling and cell growth-inhibition have been described in cell lines stably expressing elevated levels of the GnRH receptor [8-10]. So far, the ability of GnRH agonist to inhibit cell growth appears to correlate with the level of $\mathrm{GnRH}$ receptor expression at the cell surface and with the magnitude of inositol phosphate production elicited by receptor activation $[8,9]$. GnRH receptor activation coupled to $G \alpha_{q / 11}-G \beta \gamma$ proteins leads to elevation of intracellular $\mathrm{Ca}^{2+}$ levels, altered cytoskeletal function and changes in protein kinase activity, including protein kinase $\mathrm{C}$ (PKC), mitogen activated serine/ threonine kinases (MAPkinases, MAPK) and stress-activated kinases Cell-type specific effects of GnRH receptor activation on levels of phosphorylated-ERK1/2 (p-ERK1/ 2 ) have been observed $[8,9]$ which probably reflect the complexity of protein scaffolds interacting with and influencing MAPK. Effects of GnRH receptor signaling on transcription factor activity and gene expression downstream from MAPK are also likely.

Previous studies have shown that the growth of some human breast cancer cells (MCF-7, MDA-MB-435 and -231) can be inhibited when GnRH receptor is targeted $[6,7]$. How this effect is achieved is only partially understood $[4,10]$, but it may be more widely applicable to the regulation of breast cell growth.

Breast cancer is a highly heterogeneous disease arising through the accumulation of mutations in different cell types $[11,12]$. Individual cases can be characterized in increasing detail using microarray technology and complementary genomic data [13-21]. Consequently, a variety of alternative drug therapies are currently employed to treat breast cancer but new treatments aimed at 'personalized medicine' still need to be developed. Various inter- and intra-cellular signaling pathways driving cancer cell proliferation, involving steroid hormone receptors (estrogen receptor) and growth factor- or growth-factor-like receptors (the EGF receptor family and insulin-like growth factor receptor, IGF-IR), are targets for the development of new drugs [22-27]. How $\mathrm{GnRH}$ receptor signaling interacts with these pathways is an emergent area of study. Recent studies have suggested that breast cancers which possess low or zero levels of receptors for estrogen receptor, progesterone receptor and HER2 (triple negative cancers) have higher levels of GnRH receptor expression [5,7].

We analyzed GnRH receptor in 298 primary breast cancer tissue samples by quantitative immunofluorescence and screened breast cell lines for functional $\mathrm{GnRH}$ receptor. Several well characterized human breast cell lines known to possess different phenotypes and different oncogenic mutations expressing elevated levels of $\mathrm{GnRH}$ receptor were isolated following cDNA transfection. The effects of receptor activation on cell growth and intracellular signaling were studied in order to determine whether cell phenotype influences the response to $\mathrm{GnRH}$ activation and seek strategies to develop the use of GnRH receptor as a cancer therapeutic target.

\section{Methods}

Most reagents were purchased from Sigma UK, including D-Trp ${ }^{6}$ GnRH-I (D-Trp ${ }^{6}$-LHRH, Triptorelin). Antibodies for ERK-1/2 and phosphorylated-ERK1/2 were purchased from Cell Signaling Technology, UK and for $\beta$-actin, from Sigma, UK. Secondary antibodies conjugated to alkaline phosphatase were from Sigma, UK. Insulin like growth factor receptor-I (IGF-IR) inhibitor II, EGFR/ErbB2 inhibitor and phosphatidylinositol-4,5bisphosphate 3-kinase $\gamma$ (PI3K $\gamma$ ) inhibitor were purchased from Calbiochem, UK. SVCT cells [28] were purchased from ECACC, UK. MCF-7, MDA-MB-231, ZR-75-1, and T47D cells were from American Type Culture Collection (LGC, UK). The GnRH receptor stably transfected HEK293 ${ }_{\text {[SCL60] }}$ and prostate WPE-1NB26-8 cell lines described elsewhere $[8,9]$ together with HEK293 cells were used as controls for comparison. These transfected models have previously been shown to demonstrate growth responses to triptorelin $[8,9]$.

\section{Tissue microarray}

Three tissue microarrays (TMAs) were constructed with triplicate samples from 298 primary breast carcinomas as previously described [29]. The primary tissue was collected after surgical breast resection between 1999 and 2002 at the Edinburgh Breast Unit, Western General Hospital, Edinburgh [29]. The study was approved by 
the Lothian Research Ethics Committee (08/S1101/41). No informed consent (written or verbal) was obtained for use of retrospective tissue samples from the patients within this study, most of whom were deceased, since this was not deemed necessary by the Ethics Committee, who waived the need for consent. Paraffin embedded sections were prepared from the TMAs ( $3 \mu \mathrm{m}$ thick) using a microtome and then mounted onto slides. NCLGnRHR (A9E4) Leica Microsystems antibody (Novocastra Laboratories, UK) was used to detect the level of endogenous GnRH receptor immune-staining across primary breast tumours by quantitative immuno-fluorescence (using AQUAnalysis software (HistoRx Ltd., USA), as previously described [30]. Data were normalized by mean-centering to reduce systematic variation between the three TMAs.

\section{Cell culture, transfection and clone isolation}

Cells were cultured in Dulbecco's modified Eagle's medium (DMEM) with 10\% fetal bovine serum. Medium for SVCT cells was supplemented with recombinant human insulin and hydrocortisone as specified by the suppliers (ECACC, UK). HEK293 ${ }_{\text {[SCL60] }}$ and WPE-1-NB26-8 cells were cultured as described elsewhere [9]. Cells were transfected with a plasmid construct, pcDNA3.1(+) (neo) (Invitrogen, UK) containing a rat $\mathrm{GnRH}$ receptor cDNA insert, using Fugene 6 (Roche, UK) in Optimem-I (GIBCO, Invitrogen, UK). Cell clones growing in $6 \mathrm{~cm}$ dishes were picked using trypsinization in cloning cylinders (Sigma, UK) and sequentially expanded in multiwell plates and flasks prior to characterization. Sub-clones were generated by re-transfecting an individual clone with a $2.334 \mathrm{~kb}$ SV40 promoter-hygromycin phosphotransferase cDNA fragment excised from pcDNA3.1(-) (hygro) plasmid (Invitrogen, UK) using PvuII (Promega, UK) and purified following agarose gel electrophoresis.

\section{GnRH binding assay}

Levels of $\mathrm{GnRH}$ receptor at the cell surface were measured as described elsewhere, using ${ }^{125}$ I-labeled His ${ }^{5} \mathrm{D}$ $\mathrm{Tyr}^{6} \mathrm{GnRH}-\mathrm{I}$ as a radiotracer $[8,9]$. Cells were grown in 12 or 24 well plastic culture plates. The number of cells per well was determined on the day of assay using a hemocytometer to count trypsinized samples from wells prepared in parallel. For accurate determination of relative levels of $\mathrm{GnRH}$ receptor expression between different cell clones, binding assays were performed over a range of cell confluencies and the results adjusted for the number of cells per well. Non-specific binding was determined using empty wells and by the addition of 1 micromolar unlabeled mammalian GnRH-I (Sigma, UK) to displace specific binding of tracer from cells. Assays were performed in triplicate and were repeated on separate occasions to determine accuracy of measurement.

\section{In vitro cell growth assay}

Cells were seeded into 12 well plates and growth was monitored using the sulforhodamine B (SRB) staining assay described previously $[8,9]$. Two milliliters culture medium per well was sufficient to sustain cell growth over all time courses investigated. Cells were treated with a dose range of Triptorelin or vehicle (20\% propylene glycol, Sigma, UK). Similar experiments employing IGF-IR, EGFR/ErbB2 and PI3K inhibitors were performed. Assay measurements were performed in triplicate and were repeated on separate occasions. At each time point, cells were fixed by adding $1 \mathrm{ml} 25 \%$ trichloroacetic acid to each well, stored at $4^{\circ} \mathrm{C}$ for $1 \mathrm{~h}$ before gently washing and drying plates. Fixed cells were stained with $0.4 \%$ SRB in $1 \%$ acetic acid, washed, dried and dissolved in $1 \mathrm{ml} 0.1 \mathrm{M}$ Tris $\mathrm{pH} 10$. Absorbance measurements at $540 \mathrm{~nm}$ correlated with the number of cells per well.

\section{Inositol phosphate assay}

Production of ${ }^{3} \mathrm{H}$-inositol phosphates was measured in cells grown in 12 or 24 well plates as described previously $[8,9]$. Results were standardized according to the number of cells per well on the day of assay, determined using spare wells prepared in parallel. Single-dose or dose-response experiments were performed in triplicate and on separate occasions. Cells were allowed to reach 50-70\% confluence before overnight incubation in serum-free, inositol-free DMEM containing $1 \mathrm{uCi} / \mathrm{ml}^{3} \mathrm{H}$ myo inositol. Medium was replaced with $1 \mathrm{ml} /$ well HEPES + DMEM containing $0.1 \% \mathrm{BSA}$ and $10 \mathrm{mM} \mathrm{LiCl}$ and plates incubated at $37^{\circ} \mathrm{C}$ for $30 \mathrm{~min}$. This medium was then replaced with fresh medium containing vehicle or treatment and incubated at $37^{\circ} \mathrm{C}$ for $1 \mathrm{~h}$. Medium was removed and cells were fixed with $1 \mathrm{ml} /$ well $0.1 \mathrm{M}$ formic acid and incubated at $4^{\circ} \mathrm{C}$ for $30 \mathrm{~min} .{ }^{3} \mathrm{H}$-inositol phosphates were purified from the supernatant using Dowex ion exchange chromatography. The final eluate was measured using a scintillation counter.

\section{Western blotting}

Cells were grown in six-well plastic culture plates until $50-70 \%$ confluent. Some samples were washed twice with phosphate buffered saline prior to incubation in serum-free medium overnight. Cells were treated with $100 \mathrm{nM}$ Triptorelin or vehicle for specific time periods prior to lysis and harvesting. Samples were processed for western blotting as described previously using NP40 lysis buffer at at $4^{\circ} \mathrm{C}[8,9]$. For quantitative data, time points were measured in triplicate. Blots were imaged by a Typhoon phosphor-imager (GE Healthcare, UK) using enhanced chemi-fluorescence detection and analyzed using ImageQuant software (GE Healthcare, UK). 


\section{Inverse PCR analysis of DNA integration sites}

Genomic DNA was prepared from MCF-7-30 cell subclones stably transfected with SV40 promoter-hygromycin resistance DNA fragment (hygroR). Aliquots of genomic DNA were digested with a single restriction endonuclease (Promega, UK) which cuts at only one site within the hygroR DNA fragment (either AvrII, PvuI, SacII or ScaI) and relegated to form circular DNA containing flanking DNA from the genomic integration site using T4 DNA ligase. Pairs of polymerase chain reaction (PCR) primers targeting the hygroR DNA, flanking the cut-religation site were used to amplify DNA adjacent to the hygroR integration site by walking away from the hygroR sequence. Purified PCR products were cloned into pcr4 sequencing vector (Invitrogen, UK) and subjected to automated DNA sequence determination.

\section{Graphical and Statistical analyses}

Immuno-fluorescence data were analyzed by one-way ANOVA using Minitab version 16 (Minitab Inc., USA). Prism software (GraphPad, USA) was used to prepare graphs and to calculate $\mathrm{EC}_{50}$ and $\mathrm{IC}_{50}$ values. Western blots were quantified using ImageQuant software (GE Healthcare). Quantitative data were analyzed using online tools for T-test, http://easycalculation.com/statistics/standard-deviation.php and http://www.quantitativeskills.com/sisa/.

\section{Results}

$\mathrm{GnRH}$ receptor immuno-staining is highly variable across primary breast tumors but functional endogenous receptor is not detectable in breast cell lines

Tissue microarrays of 298 primary breast carcinomas from two cohorts of patients were examined by quantitative immunofluorescence (AQUA, HistoRx) for expression of GnRH receptor. The tumors were classified into three groups, triple negative phenotype (TNP, lacking ER, PR and HER2), HER2 positive or luminal [29]. There was a large dynamic range in the level of $\mathrm{GnRH}$ receptor staining (Figure 1) and the level was significantly higher in the TNP than luminal tumors ( $p$ $=0.005)$. GnRH receptor staining was also higher in grade 3 tumors compared to grade 2 tumors $(\mathrm{p}=$ 0.021).

Initial assessment of an immortalized human breast epithelial cell line (SVCT) and four human breast cancer cell lines (MCF-7, ZR-75-1, T47D and MDA-MB-231) indicated that these models did not possess detectable levels of endogenous $\mathrm{GnRH}$ receptor at the cell surface when analysed using a binding assay employing a ${ }^{125} \mathrm{I}$ labelled GnRH analog ( His $\left.^{5}-\mathrm{D}-\mathrm{Tyr}^{6}-\mathrm{GnRH}-\mathrm{I}\right)$. The cells did not accumulate ${ }^{3} \mathrm{H}$-inositol phosphates following treatment with Triptorelin (Figures 2 and 3).
Stably transfected breast cell lines can be generated with functional GnRH receptor

To model GnRH receptor positive breast cancer, the above-mentioned cell lines were transfected with a $\mathrm{GnRH}$ receptor cDNA expression construct in pcDNA3.1(+) neo and cells resistant to G418 were cloned. At least thirty G418-resistant clones derived from each cell line were screened for expression of $\mathrm{GnRH}$ receptor using the binding assay and classified according to relative level of receptor detectable at the cell surface. Relative levels of specific binding exhibited by representative clones are depicted in Figure 2A. One SVCT clone (SVCT-2) expressed high levels of GnRH receptor at the cell surface. Approximately 50\% of transfected MCF-7 clones exhibited moderate levels of specific GnRH binding (clones MCF7-6, -10, -12 and -30 in Figure 2A). A proportion of transfected ZR-75-1 cell clones also expressed moderately high levels of specific GnRH binding (see clone ZR-75-1-12 in Figure 2A). One out of 30 transfected MDA-MB-231clones expressed high levels of $\mathrm{GnRH}$ receptor, but no transfected T47D clones exhibited GnRH binding (Figure 2A). MCF-7hygro 14 cells were sub-cloned from MCF7-30 cells by re-cloning (to generate MCF-7-30-7) followed by transfection with a promoter-hygromycin resistance gene fragment (hygro) and followed again by further sub-cloning. Of these sub-clones, MCF-7hygro14 possessed the highest levels of cell surface $\mathrm{GnRH}$ receptor (see Figure 2B for examples). Analysis of the integration site of the hygromycin resistance gene, using restriction endonuclease excision, DNA circularization, inverse PCR-cloning and DNA sequencing, indicated insertion immediately $5^{\prime}$ to the CMV promoter driving transcription of the rat GnRH receptor cDNA in MCF7hygro14. In all other MCF-7hygro clones investigated, the hygro gene was inserted adjacent to the 3' flank of the rat GnRH receptor cDNA (data not shown).

Levels of cell surface GnRH receptor in SVCT-2, MCF-7hygro14 and MDA-MB231-34 were similar to levels in stably transfected HEK293 ${ }_{\text {[SCL60] }}$ cells and prostate WPE-1-NB26-8 cells described elsewhere [8,9] (Figure $2 \mathrm{~A}$ ).

The presence of functional GnRH receptor in these clones was confirmed by measuring production of ${ }^{3} \mathrm{H}$ inositol phosphates following addition of Triptorelin. SVCT-2, MCF-7hygro14 and MDA-MB-231 cells expressing rat $\mathrm{GnRH}$ receptor generated elevated levels of ${ }^{3} \mathrm{H}$ - inositol phosphates following $\mathrm{GnRH}$ receptor activation which correlated with receptor expression level (Figure 3A-C). MDA-MB-231-34 cells exhibited elevated basal phospholipase $C$ activity (Figure $3 C$ ). The dynamics of inositol phosphate accumulation following $\mathrm{GnRH}$ receptor activation were similar in the different cell lines but differences in turnover following removal 

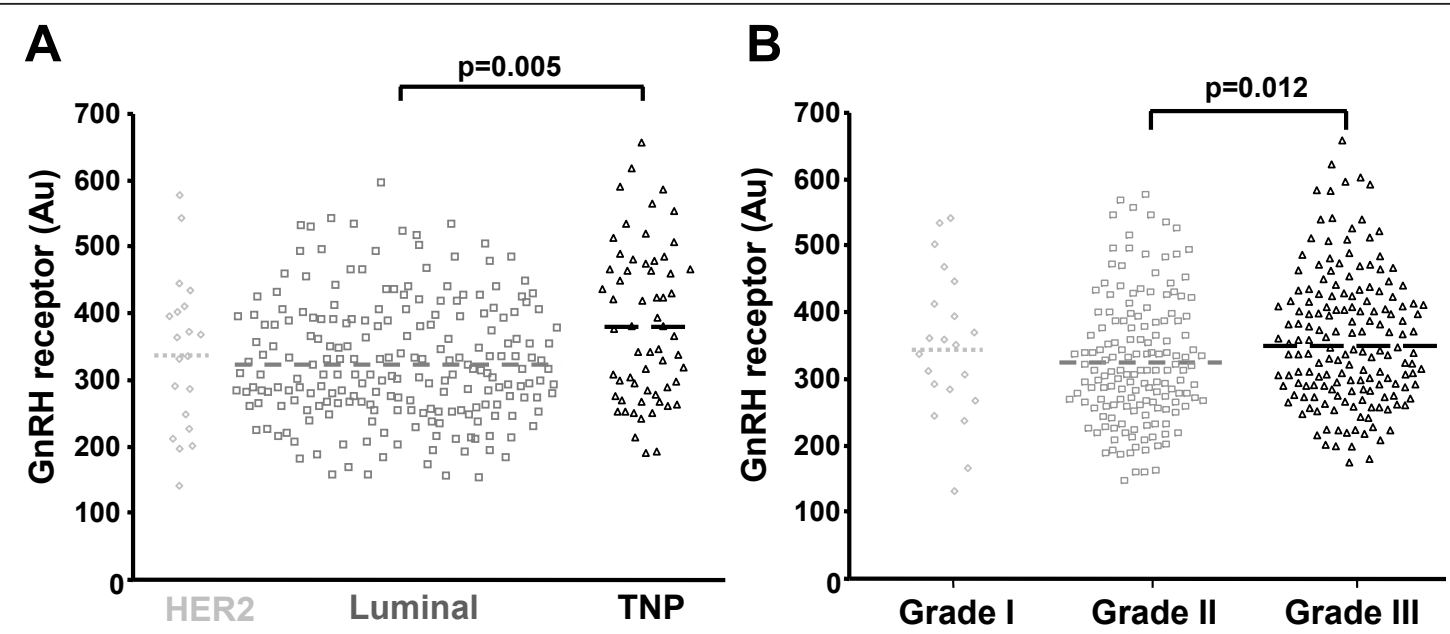

C
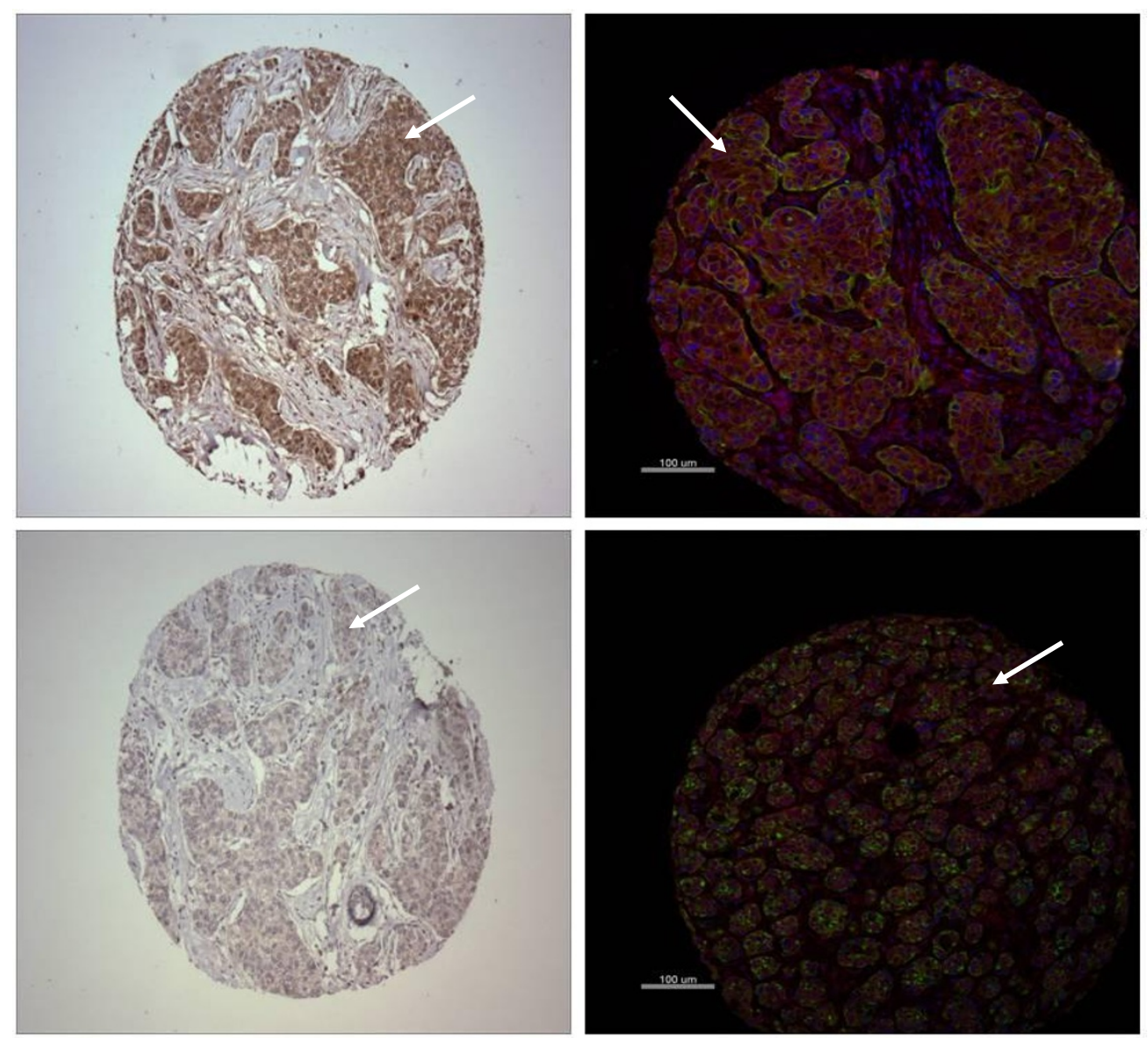

Figure $1 \mathrm{GnRH}$ receptor is expressed across a wide range in breast cancer and is highest in triple negative tumours when measured by immunostaining. Association of GnRH receptor expression and (A) Cancer type and (B) Cancer grade. Quantitative immunofluorescence (AQUA) was used to measure GnRH receptor. One way ANOVA was used to test for significant differences between subtypes, the mean for each group is shown with a dashed line. C. Representative examples of high GnRH receptor expression (top images) and low expression (bottom images). Left hand images are immunohistochemical images of tissue microarray (TMA) cores of individual breast cancer with brown staining corresponding to $\mathrm{GnRH}$ receptor expression and blue to haematoxylin staining. Right hand images are immunofluorescence images of TMA cores, with red staining corresponding to GnRH receptor expression, blue (DAPI) staining indicating cell nuclei and green staining detecting cytokeration (ie carcinoma cell) staining. White arrows indicate areas of positive expression. 


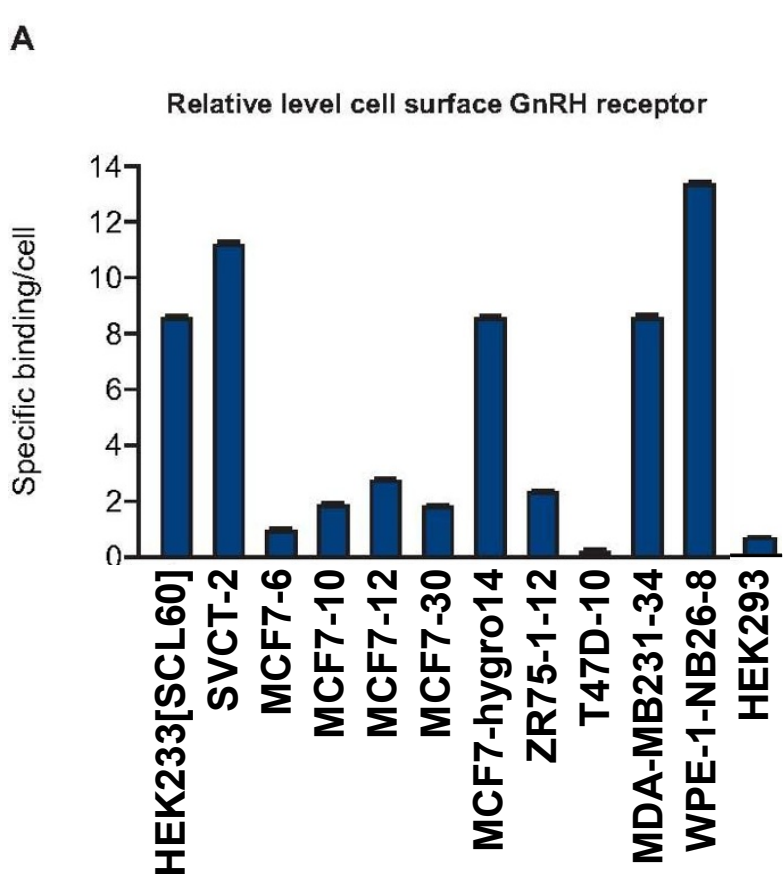

B

Relative level cell surface $\mathrm{GnRH}$ receptor

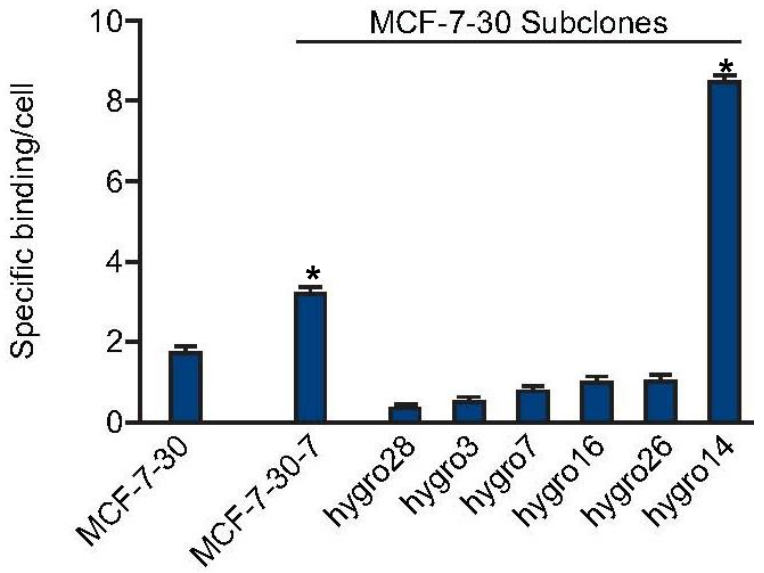

Figure 2 Stably transfected breast cell lines can be generated with functional $\mathrm{GnRH}$ receptor. Relative levels of $\mathrm{GnRH}$ at the cell surface detected by ligand binding assay in human cell lines stably transfected with rat $\mathrm{GnRH}$ receptor CDNA expression construct A. Subclones of MCF-7 clone 30 expressing modified levels of GnRH receptor at the cell surface were isolated. HEK293 and T47-D10 cells demonstrated background levels of binding. All other cell lines shown demonstrated significantly ( $p<0.05$ ANOVA) higher levels of specific binding. B. MCF-7-30-7 was subcloned from MCF-7-30 and then transfected with a Pvull SV40-hygromycin resistance gene fragment. Clones resistant to G418 and hygromycin were screened for altered GnRH receptor expression. GnRH receptor levels were elevated in clone MCF-7-30-hygro14, similar to levels in HEK293 [SCL60]. ${ }^{*} p<0.05$ (ANOVA followed by Dunnett's test) indicates significantly higher in MCF-7-30-7 and MCF-7-30-hygro14 relative to MCF-7-30 binding. of inositol phosphatase inhibition ( $\mathrm{LiCl}$ wash off) occurred according to the cell line (Figure 3D and 3E). The decrease in levels of ${ }^{3} \mathrm{H}$ - inositol phosphates was slower in SVCT-2 cells.

The GnRH super-agonist Triptorelin had little or no effect on growth compared to inhibitors of IGFR-1 or EGFR

The effects of Triptorelin on cell growth were investigated for a number of the stably transfected clones. Growth of SVCT-2 was modestly inhibited by treatment with Triptorelin $(\sim 10-18 \%$ inhibition relative to vehicle treated cells after 4 days, Figure $4 \mathrm{~A}$ ), with an $\mathrm{IC}_{50}$ of approximately 0.3 $\mathrm{nM}$. In contrast, application of IGF-IR inhibitor II resulted in complete growth inhibition accompanied by cell death, with an $\mathrm{IC}_{50}$ of $\left.\sim 11 \mu \mathrm{M}\right)$. Co-treatment with $100 \mathrm{nM}$ Triptorelin had a small additive growth-inhibitory effect, shifting the IGF-IR inhibitor growth-inhibition dose-response curve slightly to the left (Figure 4B), reducing the apparent $\mathrm{IC}_{50}$ to $\sim 9 \mu \mathrm{M}$. Treatment of SVCT-2 cells with EGFR/ ErbB2 inhibitor resulted in a 50\% growth-inhibition after 4 days, with $\mathrm{IC}_{50}$ of $\sim 2 \mu \mathrm{M}$ and co-treatment with $100 \mathrm{nM}$ Triptorelin did not significantly affect growth in these experiments (Figure 4C).

Growth of MCF-7hygro14 was not affected by GnRH receptor activation, in contrast to the effect on HEK293 [SCL60] cells (Figure 4D and 4E). Treatment of MCF7hygro14 with IGF-IR inhibitor II resulted in growth-inhibition and cell death $\left(\mathrm{IC}_{50} \sim 17 \mu \mathrm{M}\right)$ and co-treatment with $100 \mathrm{nM}$ Triptorelin had no significant effect (Figure 4F). Time-course experiments indicated that growth-inhibition could be reduced following washout of IGF-IR inhibitor II using phosphate buffered saline followed by replacement with normal culture medium. Growth-inhibition could be reduced to less than $10 \%$ over 4 days if the inhibitor was removed after a 2 hour exposure. Treatments for 6 hours or more resulted in growth-inhibition of more than $20 \%$ (Figure 4G). Treatment of MCF-7hygro14 cells with EGFR/ErbB2 inhibitor resulted in a 50\% growth inhibition after 4 days, with $\mathrm{IC}_{50}$ of $\sim 5 \mu \mathrm{M}$ and co-treatment with $100 \mathrm{nM}$ Triptorelin did not significantly affect growth in these experiments (Figure 4H). Dose-response studies using a PI3K inhibitor (ranging from $5 \mathrm{nM}$ to $7 \mu \mathrm{M}$ ) indicated that the maximum dose did not affect growth over 4 days and co-treatment with $100 \mathrm{nM}$ Triptorelin did not significantly alter this result (Figure 4I).

Growth of ZR-75-1-12 (slow growing) and MDA-MB231-34 was also not affected by treatment with Triptorelin (Figure 4J and 4K).

The levels of $p$-ERK $1 / 2$ were influenced by integration of signaling from multiple cell surface receptors which blocked responses to activated GnRH receptor

Levels of phosphorylated ERK1/2 (p-ERK1/2) in transfected MCF-7 cell clones were transiently elevated by 
A

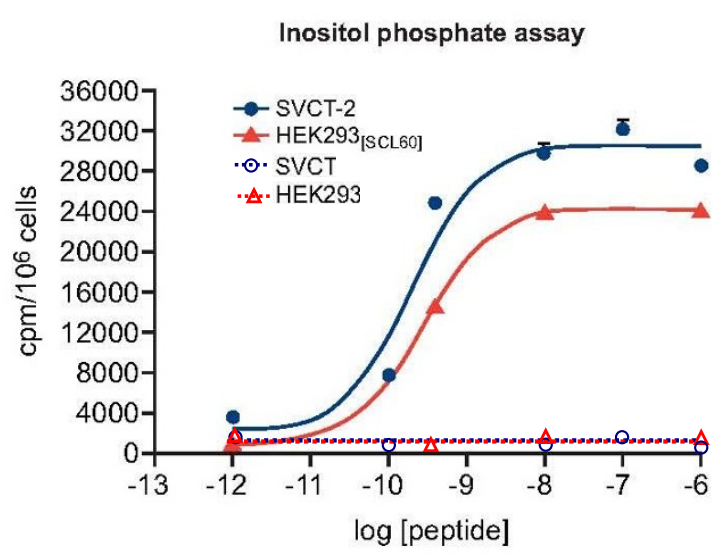

C

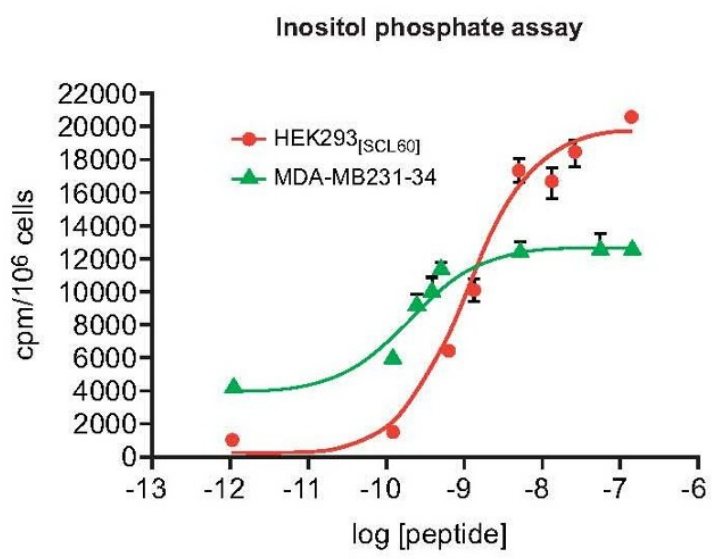

E

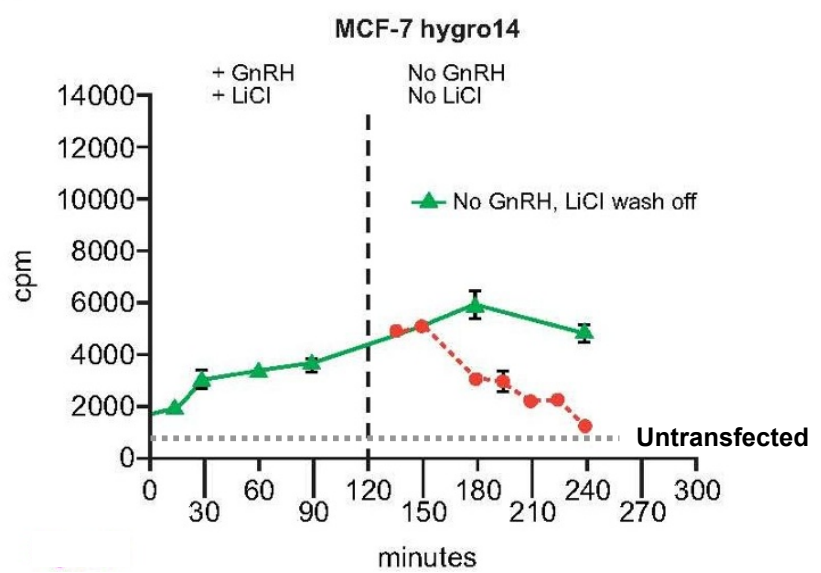

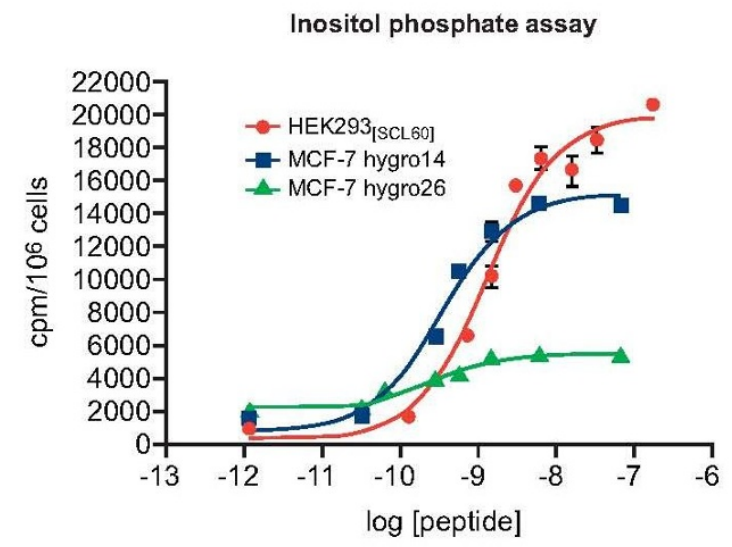

D

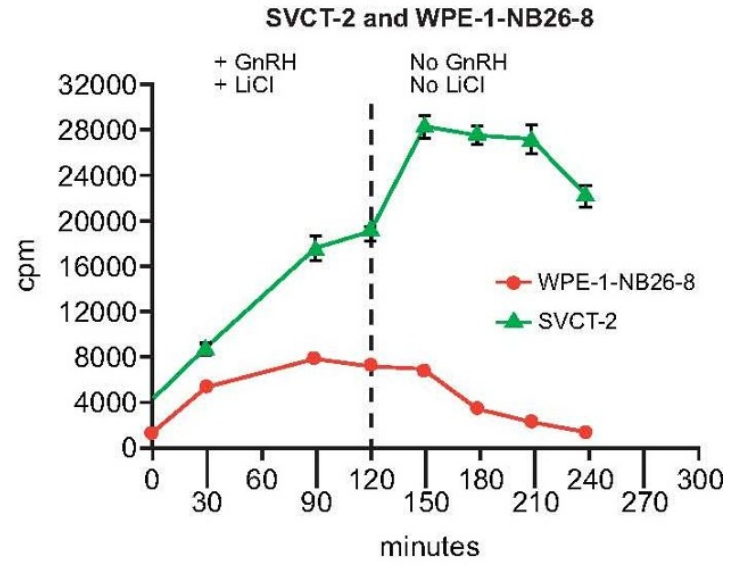

Figure 3 Dynamics of $\mathrm{GnRH}$ receptor activation following treatment with Triptorelin. Treatment of stably transfected cells with $\mathrm{GnRH}$ elicited high levels of ${ }^{3} \mathrm{H}$ - inositol phosphate (IP) production (A-C). Removal of $\mathrm{GnRH}$ and $\mathrm{LiCl}$ revealed the dynamics of ${ }^{3} \mathrm{H}$ - inositol phosphate turnover in different cell types $(D, E)$. The decrease in levels of ${ }^{3} \mathrm{H}$ - inositol phosphates was slower in SVCT-2 cells. Statistically different values ( $p<$ 0.05 ANOVA followed by Dunnett's test) compared to control values were as follows; for A, All values shown for SVCT-2 and HEK293 [SCL60] Cells > $-10 \log$ [peptide]; for B, all values shown > -10 log [peptide] for all 3 cell lines; for C, all values shown > -10 log [peptide] for both cell lines; for D, all values shown for SVCT-2 and all values up to $180 \mathrm{~min}$ for WPE-1-NB26-8; for E, all values from 30 min to $180 \mathrm{~min}$. 
A

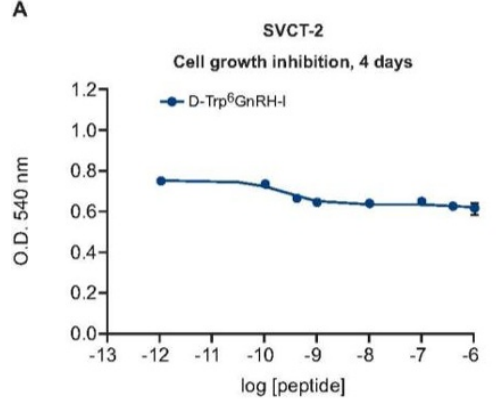

D

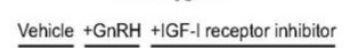

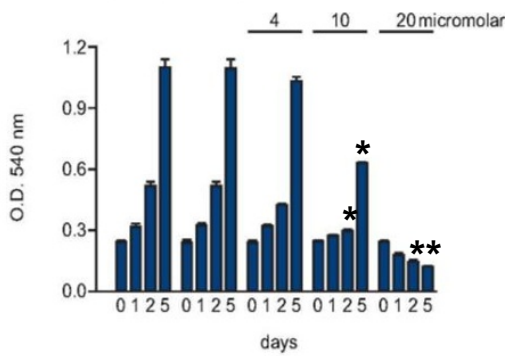

G

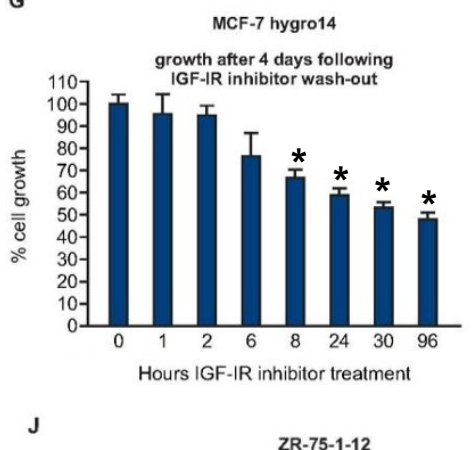

J

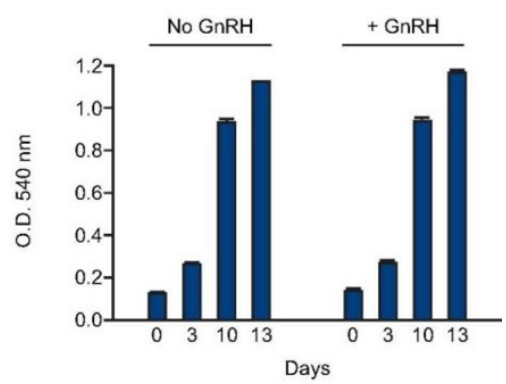

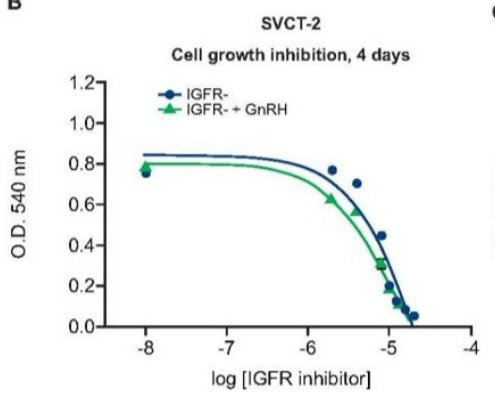

C

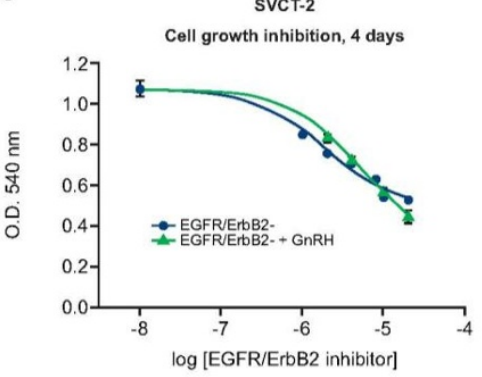

E

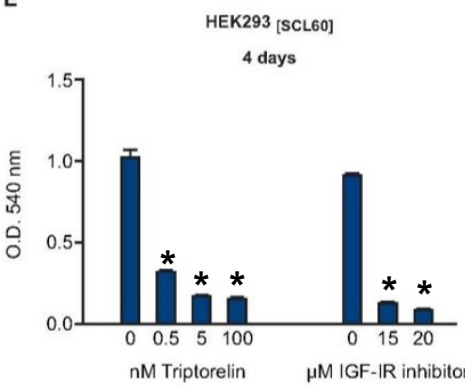

$\mathbf{F}$

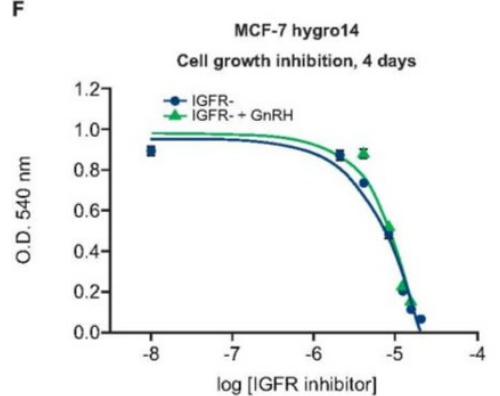

I

H
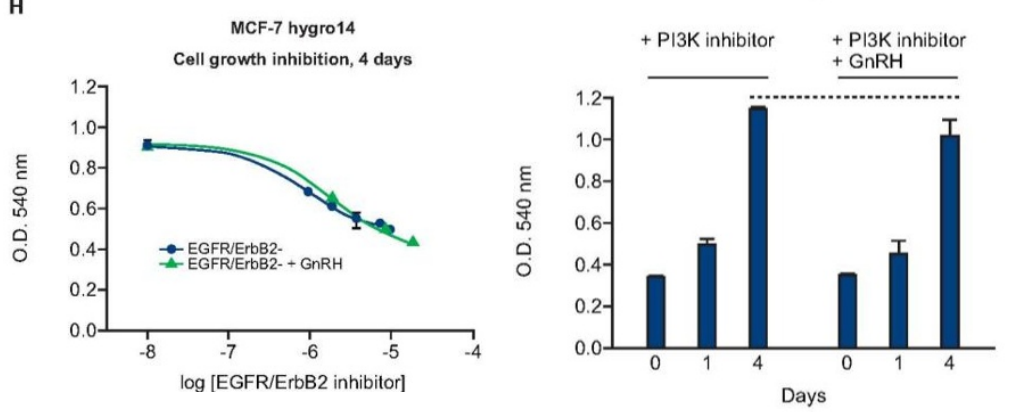

K

MDA-MB-231-34

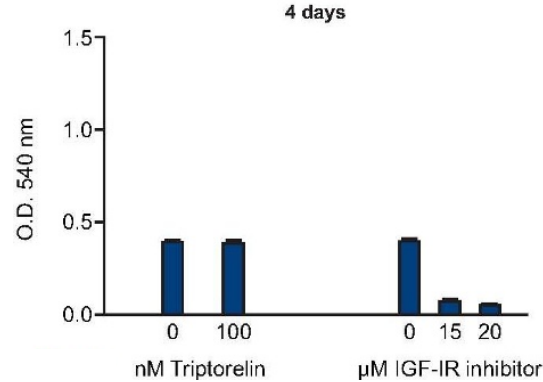

Figure 4 The effect of Triptorelin on growth of cells stably transfected with GnRH. A. Growth of SVCT-2 after 4 days was marginally inhibited (10-18\%) by treatment with Triptorelin. However, cell growth was effectively inhibited by IGF-IR inhibitor II and co-treatment with Triptorelin exerted a small additive effect (B). EGFR/ErbB2 inhibitor reduced SVCT-2 cell growth, but co-treatment with Triptorelin had no effect (C). Growth of MCF-7-30-7hygro14 cells was not affected by treatment with 100 nM Triptorelin (D), unlike HEK293 [SCL60] cells (E) after 4 days. Growth and survival were inhibited by IGF-IR inhibitor II but co-treatment with Triptorelin had no effect (F). Transient exposure to $15 \mu M$ IGF-IR inhibitor II for up to 2 hours resulted in less than 10\% growth-inhibition after 4 days, longer exposures resulted in more extensive growthinhibition (G). Growth of MCF-7-30-7hygro14 cells was inhibited by EGFR/ErbB2 inhibitor but not affected by treatment with $7 \mu$ M PI3K $\gamma$ inhibitor and co-treatment with 100 nM Triptorelin exerted no significant growth-inhibition (H and I). Growth of ZR75-1-12 (J) and MDA-MB-231-34 (K) was unaffected by treatment with $100 \mathrm{nM}$ Triptorelin. * $\mathrm{p}<0.05$ (ANOVA followed by Dunnett's test). 
GnRH receptor activation provided cells were incubated in serum-free medium overnight prior to stimulation. In the presence of serum, GnRH receptor activation did not significantly affect levels of p-ERK1/2 (Figure 5). Levels of p-ERK1/2 were not altered by GnRH receptor activation in serum-starved MDA-MB231-34 cells (Figure $5 \mathrm{~A})$.

Treatment of MCF-7hygro14 cells with 15-20 $\mu \mathrm{M}$ IGF-IR inhibitor II caused a rapid (within 30 minutes) and permanent decrease in levels of $\mathrm{p}-\mathrm{ERK} 1 / 2$ in the presence of serum. The inhibitor did not elicit this effect in MDA-MB-231-34 cells (Figure 5C). When the inhibitor was washed off MCF-7hygro14 cells after a 1 $\mathrm{h}$ exposure followed by addition of medium containing serum, there was a rapid hyper-phosphorylation of ERK1/2 followed by a slow decline. Addition of 100 $\mathrm{nM}$ Triptorelin at the time of inhibitor wash-off did not significantly alter the intensity or dynamics of ERK1/2 phosphorylation (Figure 5D). The effects of IGFR-IR inhibitor II on p-ERK1/2 levels were similar in HEK293 ${ }_{\text {[SCL60] }}$ cells, with the exception that rapid hyper-phosphorylation of ERK1/2 did not occur when inhibitor was washed off unless Triptorelin was added (Figure 5D).

\section{Discussion}

In this study, GnRH receptor immunostaining was found to be expressed over a wide dynamic range in breast cancer cases and its expression was significantly higher in patients with triple-negative disease, consistent with previous data [5,7]. High levels of expression were also observed in subgroups of luminal and HER2 breast cancers.

To investigate $\mathrm{GnRH}$ receptor function in breast cells, an immortalized human breast epithelial cell line (SVCT) and four well defined human breast cancer cell lines (MCF-7, MDA-MB-231, ZR-75-1 and T47D) were examined. None of the native cell lines possessed functional cell surface $\mathrm{GnRH}$ receptor detectable by binding assay or by induction of inositol phosphate production. Cell clones expressing high levels of GnRH receptor compared to other model systems could be isolated following transfection with $\mathrm{GnRH}$ receptor cDNA. In selected clones, treatment with GnRH agonist elicited high levels of inositol phosphate production, indicating that the receptor was functionally intact.

Despite the expression of high levels of GnRH receptor in SVCT-2, MCF-7hygro14 and MDA-MB-231-4, their growth was only marginally inhibited (SVCT-2) or was unaffected by treatment with the GnRH super-agonist Triptorelin in contrast to other model systems. By contrast, the growth of all cells was sensitive to IGF-IR or EGFR inhibitors (Figure 4). Analyses of receptor signaling indicated that Triptorelin significantly affected levels of phosphorylated ERK1/2 (p-ERK1/2) only in serum-starved transfected MCF-7 cells and GnRH receptor activation was unable to impinge on levels of p-ERK1/2 in MDA-MB-231-34 cells (Figure 5). In contrast, transient alterations in the levels of $\mathrm{p}$-ERK1/2 do occur in cells which are growth-inhibited by $\mathrm{GnRH}$ receptor activation, even in the presence of growth factors (HEK293 ${ }_{\text {[SCL60] }}$ B35-2 neuroblastoma and prostate WPE-1-NB26-3) [8,9].

The lack of effect of GnRH agonist treatment on the growth of breast cell lines, and its limited effect on pERK1/2, may be explained by features of the growthassociated intracellular signaling apparatus within each breast cell line [31-39].

Growth of SVCT-2 cells was inhibited by IGF-IR inhibitor II, an inhibitor of ligand-induced IGF receptor auto-phosphorylation. Combined treatment with Triptorelin increased growth inhibition marginally (Figure 4). Thus the IGF-I signaling pathway is a candidate which may block anti-proliferative signaling by $\mathrm{GnRH}$ agonists in SVCT-2, consistent with transformation by SV40 [31,32].

Growth of MCF-7hygro14 was inhibited with IGF-IR inhibitor (Figure $4, \mathrm{IC}_{50}$ was $\sim 17 \mu \mathrm{M}$ for these cells), consistent with the established growth-stimulatory effects of IGF-I in MCF-7 cells [33-36]. Furthermore, significant growth-inhibition over 4 days could be elicited by a brief exposure to IGF-IR inhibitor (2 hours). In MCF-7hygro14, the IGF-IR inhibitor caused a rapid decrease in the levels of $\mathrm{p}$-ERK1/2, within 30 minutes (Figure 5) but it did not affect levels of p-ERK1/2 in MDA-MB-231-34 cells despite inhibiting their growth also. This is consistent with differences in signaling between the two cell lines [38] and the occurrence of mutationally activated k-Ras and B-Raf in MDA-MB231-34 cells [37].

When IGF-IR inhibitor was washed off MCF-7hygro14 cells there was a rapid hyper-phosphorylation of ERK1/ 2 , followed by a slow decline to basal levels, which was not influenced by GnRH receptor activation. Growth factors in the medium probably stimulate resurgence in ERK phosphorylation.

In comparison to MCF-7hygro14 cells, growth of HEK293 [SCL60] cells was also inhibited by IGF-IR inhibitor but levels of p-ERK1/2 were relatively low in these cells compared to the breast cancer cells. Furthermore, hyper-phosphorylation of ERK1/2 did not occur in HEK293 ${ }_{\text {[SCL60] }}$ cells following removal of IGF-IR inhibitor. However, activation of GnRH receptor with Triptorelin following IGF-IR inhibitor wash-off did intensely elevate p-ERK1/2 levels (Figure 5). Intense transient activation of ERK-1/2 correlates with cell growth inhibition in HEK293 ${ }_{\text {[SCL60] }}$ cells $[8,9]$. This may not be the case in MCF-7 cells. 


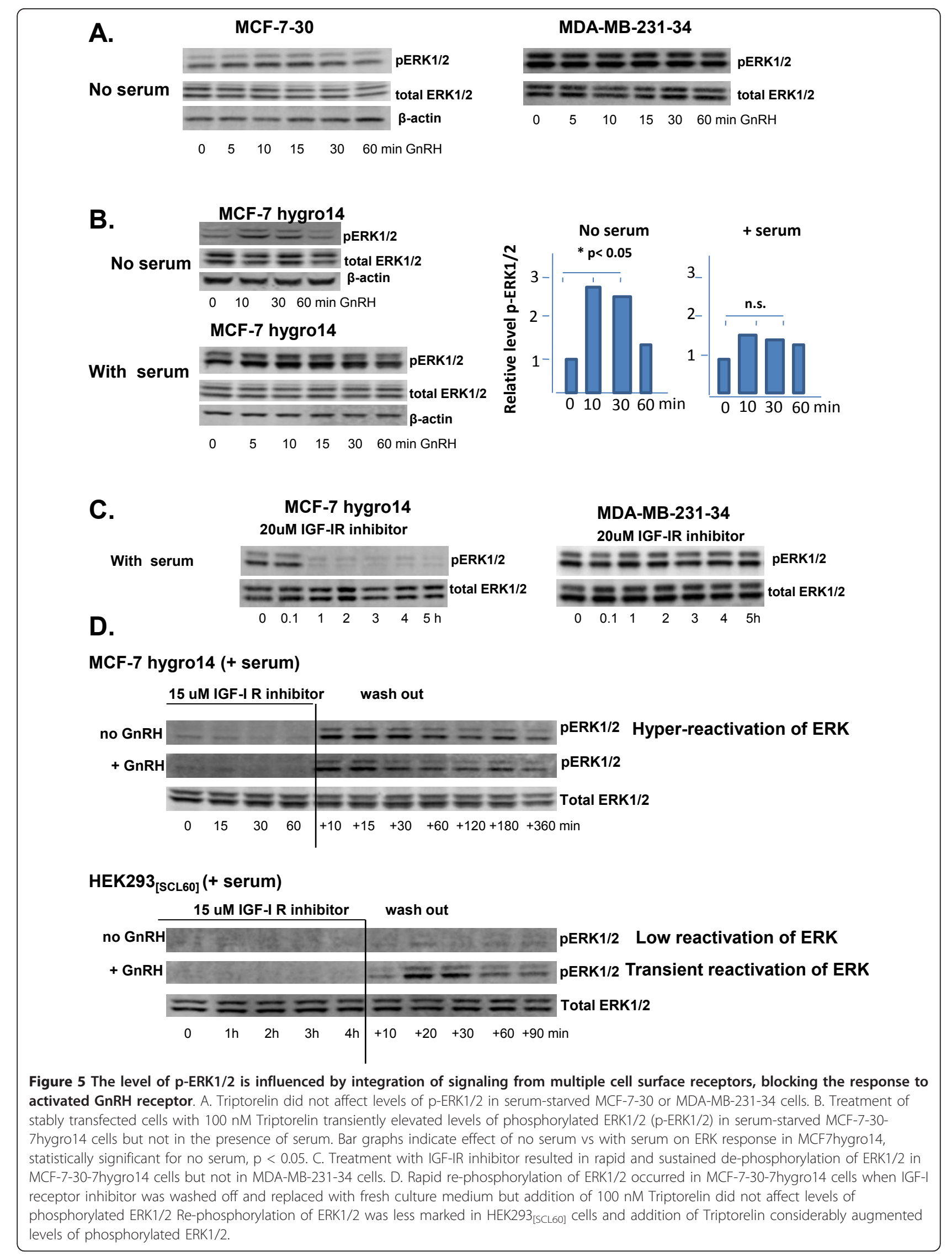


Perhaps these differences in the modulation of $\mathrm{p}$-ERK $1 / 2$ levels indicate that the IGF-IR-Ras-PI3K complex (which rapidly reforms when the IGF-IR inhibitor is washed off) is much more active in MCF-7 cells than in HEK293 cells. In MDA-MB231-34 cells, the activating c-Kirsten Ras and B-Raf mutations may be important for maintaining $\mathrm{p}$-ERK1/2 levels independent of the effects of IGF-IR inhibitor on cell growth [37-39].

Estrogen receptor $\alpha$ influences IGF-IR, EGFR, Akt and MAPK activity by recruiting PI3K and Src to a microtubule-based protein scaffold [40]. Although ER $\alpha$ is present in MCF-7 cells and estrogen promotes MCF-7 growth, it is not endogenously expressed in MDA-MB231 or HEK293 cells [40]. Hence, ER $\alpha$ may influence the signaling response to $\mathrm{GnRH}$ in MCF-7hygro14 relative to the other cells.

Differential signaling responses in MCF-7 and MDAMB-231 cells (Figure 5) may reflect, at least in part, the activating mutations in PI3KCA and c-Kirsten Ras respectively $[37,38]$ which impact upon MAPK-ERK1/2 activity. Other features of MDA-MB-231 cells [39] may contribute to the elevated basal phospholipase $\mathrm{C}$ activity in MDA-MB-231-34 (Figure 2C), where altered PKC activity may affect MAPK-ERK1/2 status in these cells.

Downstream from receptor-proximal interactions involving PI3K, Akt and PKC compete at the level of Raf-1 to exert opposite effects on the MAPK pathway (inhibitory and stimulatory, respectively) [41-44]. Perhaps constitutive activation of PI3K in MCF-7 cells abolishes the ability of GnRH-mediated PKC activation to impact upon Raf-1 in MCF-7-hygro14 cells. Interestingly, PKC $\alpha$-mediated inhibition of Akt activity has been proposed as a mechanism for $\mathrm{GnRH}$-mediated growth-inhibition in a mouse pituitary gonadotrope cell line immortalized with Sv40 T antigen [10].

Understanding how activating mutations in c-Kirsten Ras and B-Raf in MDA-MB-231 cells impact on GnRH receptor signaling to the MAPK cascade requires further investigation. In the presence of serum, levels of $\mathrm{p}$ ERK1/2 are influenced by integration of signaling from multiple cell surface receptors (including FGF receptor in MDA-MB-231) [36], and this combined signaling probably prevents $\mathrm{GnRH}$-mediated cell growth inhibition. The lack of effect of PI3K inhibitor on MCF7hygro14 cell growth (Figure 4) suggests that simultaneous inhibition of both Akt and Ras signaling may be required to inhibit the growth of $\mathrm{GnRH}$ receptor positive cells $[45,46]$.

\section{Conclusions}

We discovered that $\mathrm{GnRH}$ receptor protein expression is often associated with triple negative breast cancer; however functional cell surface GnRH receptor levels are rare in cultured breast cell lines. The demonstration that a GnRH analog is ineffective in inhibiting growth of breast cancer cell lines expressing high levels of the $\mathrm{GnRH}$ receptor, despite eliciting robust signalling, provides a valuable tool for determining the intracellular context which does (eg HEK 293 and WPE-1-NB26-8) or does not (breast cancer cell lines) facilitate anti-proliferative effects of $\mathrm{GnRH}$ signalling. Creation and study of GnRH receptor positive models indicated that mitogenic signaling sensitive to IGF-IR inhibitor outweighs the potential growth-inhibitory effects of GnRH receptor activation in stably transfected breast cell lines. These results suggest that combinatorial strategies with growth factor inhibitors will be needed to enhance GnRH antiproliferative effects in breast cancer.

\section{Abbreviations}

$\mathrm{GnRH}$ : gonadotropin releasing hormone; IGF-l: insulin-like growth factor 1; EGF: epidermal growth factor; IGF-IR: insulin-like growth factor 1 receptor; IGF-IR inhibitor II: [N-(2-Methoxy-5-chlorophenyl)-N'-(2-methylquinolin-4-yl)urea]; EGFR: epidermal growth factor receptor; EGFR/ErbB2 inhibitor: 4-(4Benzyloxyanilino)-6,7-dimethoxyquinazoline]; ERa: estrogen receptor alpha; PI3K: phosphatidylinositol-4,5-bisphosphate 3-kinase; PI3KCA: PI3K catalytic subunit, PI3Ky inhibitor- (5-Quinoxalin-6-ylmethylene-thiazolidine-2,4-dione); MEK, MAPK: mitogen activated protein kinase; ERK: extracellular signal regulated kinase; RACK: receptor for activated C- kinase.

\section{Acknowledgements}

We are grateful to Breakthrough Breast Cancer for funding and thank Ronnie Grant for help with the graphics.

\section{Author details}

${ }^{1}$ Medical Research Council Human Reproductive Sciences Unit, The Queen's Medical Research Institute, Little France Crescent, Old Dalkeith Road, Edinburgh EH16 4TJ, UK. ²Breakthrough Research Unit and Division of Pathology, Institute of Genetics and Molecular Medicine, University of Edinburgh, Crewe Road, Edinburgh, EH4 2XU, UK.

\section{Authors' contributions}

All authors read and approved the final manuscript. KM performed experiments, analyzed data and wrote the manuscript, CM, NM, IC and DF performed experiments and analyzed data, AHS and SPL assisted manuscript production and data interpretation, DJH and RPM contributed intellectually.

\section{Competing interests}

The authors declare that they have no competing interests.

Received: 25 July 2011 Accepted: 3 November 2011

Published: 3 November 2011

\section{References}

1. LHRH-agonists in Early Breast Cancer Overview group, Cuzick J, Ambroisine L, Davidson N, Jakesz R, Kaufmann M, Regan M, Sainsbury R: Use of luteinising-hormone-releasing hormone agonists as adjuvant treatment in premenopausal patients with hormone-receptor-positive breast cancer: a meta-analysis of individual patient data from randomised adjuvant trials. Lancet 2007, 369:1711-2173.

2. Gnant $M$, Mlineritsch $B$, Schippinger $W$, Luschin-Ebengreuth $G$, Pöstlberger S, Menzel C, Jakesz R, Seifert M, Hubalek M, Bjelic-Radisic V, Samonigg H, Tausch C, Eidtmann H, Steger G, Kwasny W, Dubsky P, Fridrik M, Fitzal F, Stierer M, Rücklinger E, Greil R, ABCSG-12 Trial Investigators, Marth C: Endocrine therapy plus zoledronic acid in premenopausal breast cancer. New Engl J Med 2009, 360:679-691.

3. Segal-Abramson T, Kitroser $H$, Levy J, Schally AV, Sharoni Y: Direct effects of luteinizing hormone-releasing hormone agonists and antagonists on MCF-7 mammary cancer cells. Proc Natl Acad Sci USA 1992, 89:2336-2339. 
4. Hershkovitz E, Marbach M, Bosin E, Levy J, Roberts CT Jr, LeRoith D, Schally AV, Sharoni Y: Luteinizing hormone-releasing hormone antagonists interfere with autocrine and paracrine growth stimulation of MCF-7 mammary cancer cells by insulin-like growth factors. J Clin Endocrinol Metab 1993, 77:963-968.

5. Buchholz S, Seitz S, Schally AV, Engel JB, Rick FG, Szalontay L, Hohla F, Krishan A, Papadia A, Gaiser T, Brockhoff G, Ortmann O, Diedrich K, Köster F: Triple-negative breast cancers express receptors for luteinizing hormone-releasing hormone (LHRH) and respond to LHRH antagonist cetrorelix with growth inhibition. Int J Oncol 2009, 35:789-796.

6. Everest HM, Hislop JN, Harding T, Uney JB, Flynn A, Millar RP, McArdle CA: Signaling and antiproliferative effects mediated by $\mathrm{GnRH}$ receptors after expression in breast cancer cells using recombinant adenovirus. Endocrinology 2001, 142:4663-4672.

7. Schubert A, Hawighorst T, Emons G, Gründker C: Agonists and antagonists of $\mathrm{GnRH}-\mathrm{I}$ and -II reduce metastasis formation by triple-negative human breast cancer cells in vivo. Breast Cancer Res Treat 2011.

8. Morgan K, Stewart AJ, Miller N, Mullen P, Muir M, Dodds M, Medda F, Harrison D, Langdon S, Millar RP: Gonadotropin-releasing hormone receptor levels and cell context affect tumor cell responses to agonist in vitro and in vivo. Cancer Res 2008, 68:6331-6340.

9. Morgan K, Stavrou E, Leighton SP, Miller N, Sellar R, Millar RP: Elevated $\mathrm{GnRH}$ receptor expression plus $\mathrm{GnRH}$ agonist treatment inhibits the growth of a subset of papillomavirus 18-immortalized human prostate cells. Prostate 2010, 71:915-928.

10. Rose A, Froment P, Perrot V, Quon MJ, LeRoith D, Dupont J: The luteinizing hormone-releasing hormone inhibits the anti-apoptotic activity of insulin-like growth factor- 1 in pituitary alphaT3 cells by protein kinase Calpha-mediated negative regulation of Akt. J Biol Chem 2004, 279:52500-52516.

11. Sims AH, Howell A, Howell SJ, Clarke RB: Origins of breast cancer subtypes and therapeutic implications. Nat Clin Pract Oncol 2007, 4:516-525.

12. Weigelt B, Reis-Filho JS: Histological and molecular types of breast cancer: is there a unifying taxonomy? Nat Rev Clin Oncol 2009, 6:718-730.

13. Teschendorff $A E$, Caldas $C$ : The breast cancer somatic 'muta-ome': tackling the complexity. Breast Cancer Res 2009, 11:301.

14. Dati C, Muraca R, Tazartes O, Antoniotti S, Perroteau I, Giai M, Cortese P, Sismondi $P$, Saglio G, De Bortoli M: c-erbB-2 and ras expression levels in breast cancer are correlated and show a co-operative association with unfavorable clinical outcome. Int J Cancer 1991, 47:833-838.

15. Kurebayashi J: Biological and clinical significance of HER2 overexpression in breast cancer. Breast Cancer 2001, 8:45-51.

16. Done SJ, Arneson NC, Ozçelik H, Redston M, Andrulis IL: p53 mutations in mammary ductal carcinoma in situ but not in epithelial hyperplasias. Cancer Res 1998, 58:785-789.

17. Stemke-Hale K, Gonzalez-Angulo AM, Lluch A, Neve RM, Kuo WL, Davies M, Carey M, Hu Z, Guan Y, Sahin A, Symmans WF, Pusztai L, Nolden LK, Horlings H, Berns K, Hung MC, van de Vijver MJ, Valero V, Gray JW, Bernards R, Mills GB, Hennessy BT: An integrative genomic and proteomic analysis of PIK3CA, PTEN, and AKT mutations in breast cancer. Cancer Res 2008, 68:6084-6091.

18. López-Knowles E, OToole SA, McNeil CM, Millar EK, Qiu MR, Crea P, Daly RJ, Musgrove EA, Sutherland RL: PI3K pathway activation in breast cancer is associated with the basal-like phenotype and cancer-specific mortality. Int J Cancer 2010, 126:1121-1131.

19. Troxell ML, Levine J, Beadling C, Warrick A, Dunlap J, Presnell A, Patterson J, Shukla A, Olson NR, Heinrich MC, Corless CL: High prevalence of PIK3CA/ AKT pathway mutations in papillary neoplasms of the breast. Mod Pathol 2010, 23:27-37

20. Yang J, Ren Y, Wang L, Li B, Chen Y, Zhao W, Xu W, Li T, Dai F: PTEN mutation spectrum in breast cancers and breast hyperplasia. $J$ Cance Res Clin Oncol 2010, 136:1303-1311.

21. Loi S, Sotiriou C, Haibe-Kains B, Lallemand F, Conus NM, Piccart MJ, Speed TP, McArthur GA: Gene expression profiling identifies activated growth factor signaling in poor prognosis (Luminal-B) estrogen receptor positive breast cancer. BMC Med Genomics 2009, 2:37.

22. Cullen KJ, Allison A, Martire I, Ellis M, Singer C: Insulin-like growth factor expression in breast cancer epithelium and stroma. Breast Cancer Res Treat 1992, 22:21-29.
23. Brünner N, Moser C, Clarke R, Cullen K: IGF-I and IGF-II expression in human breast cancer xenografts: relationship to hormone independence. Breast Cancer Res Treat 1992, 22:39-45.

24. Zhang $X$, Yee D: Tyrosine kinase signalling in breast cancer: insulin-like growth factors and their receptors in breast cancer. Breast Cancer Res 2000, 2:170-175.

25. Maor S, Yosepovich A, Papa MZ, Yarden Rl, Mayer D, Friedman E, Werner H: Elevated insulin-like growth factor-I receptor (IGF-IR) levels in primary breast tumors associated with BRCA1 mutations. Cancer Lett 2007, 257:236-243.

26. Law JH, Habibi G, Hu K, Masoudi H, Wang MY, Stratford AL, Park E, Gee JM, Finlay P, Jones HE, Nicholson RI, Carboni J, Gottardis M, Pollak M, Dunn SE: Phosphorylated insulin-like growth factor-l/insulin receptor is present in all breast cancer subtypes and is related to poor survival. Cancer Res 2008, 68:10238-10246.

27. Sabbatini P, Rowand JL, Groy A, Korenchuk S, Liu Q, Atkins C, Dumble M, Yang J, Anderson K, Wilson BJ, Emmitte KA, Rabindran SK, Kumar R: Antitumor activity of GSK1904529A, a small-molecule inhibitor of the insulin-like growth factor-I receptor tyrosine kinase. Clin Cancer Res 2009, 15:3058-3067.

28. Chang SE: In vitro transformation of human epithelial cells. Biochimica et Biophysica Acta 1986, 823:161-194.

29. Aitken SJ, Thomas JS, Langdon SP, Harrison DJ, Faratian D: Quantitative analysis of changes in ER, PR and HER2 expression in primary breast cancer and paired nodal metastases. Ann Oncol 2010, 21:1254-1261.

30. Katz E, Dubois-Marshall S, Sims AH, Faratian D, Li J, Smith ES, Quinn JA, Edward M, Meehan RR, Evans EE, Langdon SP, Harrison DJ: A gene on the HER2 amplicon, C35, is an oncogene in breast cancer whose actions are prevented by inhibition of Syk. Br J Cancer 2010, 103:401-10.

31. Cantalupo PG, Sáenz-Robles MT, Rathi AV, Beerman RW, Patterson WH, Whitehead RH, Pipas JM: Cell-type specific regulation of gene expression by simian virus $40 \mathrm{~T}$ antigens. Virology 2009, 386:183-191.

32. Wu A, Chen J, Baserga R: The role of insulin receptor substrate-1 in the oncogenicity of simian virus $40 \mathrm{~T}$ antigen. Cell Cycle 2008, 7:1999-2002.

33. Hollestelle A, Elstrodt F, Nagel JH, Kallemeijn WW, Schutte M: Phosphatidylinositol-3-OH kinase or RAS pathway mutations in human breast cancer cell lines. Mol Cancer Res 2007, 5:195-201.

34. Ahmad T, Farnie G, Bundred NJ, Anderson NG: The mitogenic action of insulin-like growth factor I in normal human mammary epithelial cells requires the epidermal growth factor receptor tyrosine kinase. J Biol Chem 2004, 279:1713-1719.

35. Surmacz E, Bartucci M: Role of estrogen receptor alpha in modulating IGF-I receptor signaling and function in breast cancer. J Exp Clin Cancer Res 2004, 23:385-94.

36. Kahlert S, Nuedling S, van Eickels M, Vetter H, Meyer R, Grohe C: Estrogen receptor alpha rapidly activates the IGF-1 receptor pathway. J Biol Chem 2000, 275:18447-18453.

37. Kozma SC, Bogaard ME, Buser K, Saurer SM, Bos JL, Groner B, Hynes NE: The human c-Kirsten ras gene is activated by a novel mutation in codon 13 in the breast carcinoma cell line MDA-MB231. Nucleic Acids Res 1987, 15:5963-5971.

38. Bartucci M, Morelli C, Mauro L, Andò S, Surmacz E: Differential insulin-like growth factor I receptor signaling and function in estrogen receptor (ER)-positive MCF-7 and ER-negative MDA-MB-231 breast cancer cells. Cancer Res 2001, 61:6747-6754.

39. Browaeys-Poly E, Perdereau D, Lescuyer A, Burnol AF, Cailliau K: Akt interaction with $P L C$ (gamma) regulates the $G(2) / M$ transition triggered by FGF receptors from MDA-MB-231 breast cancer cells. Anticancer Res 2009, 29:4965-4969.

40. Manavathi B, Acconcia F, Rayala SK, Kumar R: An inherent role of microtubule network in the action of nuclear receptor. Proc Natl Acad Sci USA 2006, 103:15981-15986

41. Callejas-Valera JL, Guinea-Viniegra J, Ramírez-Castillejo C, Recio JA, GalanMoya E, Martinez N, Rojas JM, Ramón y Cajal S, Sánchez-Prieto R: E1a gene expression blocks the ERK $1 / 2$ signaling pathway by promoting nuclear localization and MKP up-regulation: implication in v-H-Ras-induced senescence. J Biol Chem 2008, 283:13450-13458,

42. Kolch W, Heidecker $G$, Kochs $G$, Hummel R, Vahidi H, Mischak $H$ Finkenzeller G, Marmé D, Rapp UR: Protein kinase C alpha activates RAF-1 by direct phosphorylation. Nature 1993, 364:249-252. 
43. Zimmermann S, Moelling K: Phosphorylation and regulation of Raf by Akt (protein kinase B). Science 1999, 286:1741-1744.

44. Moelling K, Schad K, Bosse M, Zimmermann S, Schweneker M: Regulation of Raf-Akt Cross-talk. J Biol Chem 2002, 277:31099-31106.

45. Lobenhofer EK, Huper G, Iglehart JD, Marks JR: Inhibition of mitogenactivated protein kinase and phosphatidylinositol 3-kinase activity in MCF-7 cells prevents estrogen-induced mitogenesis. Cell Growth Differ 2000, 11:99-110.

46. Fukazawa H, Noguchi K, Murakami Y, Uehara Y: Mitogen-activated protein/ extracellular signal-regulated kinase kinase (MEK) inhibitors restore anoikis sensitivity in human breast cancer cell lines with a constitutively activated extracellular-regulated kinase (ERK) pathway. Mol Cancer Ther 2002, 1:303-309.

\section{Pre-publication history}

The pre-publication history for this paper can be accessed here: http://www.biomedcentral.com/1471-2407/11/476/prepub

doi:10.1186/1471-2407-11-476

Cite this article as: Morgan et al:: GnRH receptor activation competes at a low level with growth signaling in stably transfected human breast cell lines. BMC Cancer 2011 11:476.

\section{Submit your next manuscript to BioMed Central} and take full advantage of:

- Convenient online submission

- Thorough peer review

- No space constraints or color figure charges

- Immediate publication on acceptance

- Inclusion in PubMed, CAS, Scopus and Google Scholar

- Research which is freely available for redistribution

Submit your manuscript at www.biomedcentral.com/submit 